\title{
光を化学エネルギーに変える 高分子
}

\section{金子 正夫 · 山田璪}

Masao Kaneko, Akira Yamada, 理化学研究所

\section{1.はじめに}

近い将来に乱ける化石然料の枯渴が明白となった現 在, 新エネルギー開発は主要な世界的研究課題の一つ である(1),2)，地表の太陽エネルギー総照射量は人類の エネルギー総使用量の 1 万倍以上に及び，效率高い変 换を行なえば十分需要を満たせる量を持つ、ここでは 太陽光スペクトルの主成分である可視光の化学エネル ギーへの変換について展望する.

緑色植物は化学的方法で太陽エネルギーを変換, 貯 藏して特り，しか子全生物はこれ认依存している，光 合成システムを模做した人工的な簡単な合成系でも太 陽エネルギーの変換ができるはずである，物理的変換 飞対して化学的変換の場合は, 物質 (化学エネルギー) の形で貯蔵できる有利性がある.

光エネルギーの化学的変換設計の要点は, 光による 電荷分離, 電子伝達, 特よび触媒サイトに拈ける化学 反応沙るが，短寿命励起種の反応，逆反応飞よるエ ネルギ一損失などの難問も控えている，一方，光合成 系は特異的な不均一反応場の利用によりこれらを解決 している、したがって人工系で変換を行なら場合，高 能率なエネルギー損失の少ない反応場を設計すること が最大の課題とならう。ここに反応試剤として，ある いは特異な反応場を形成する matrix としての高分子 の重要な役割がある2).

光を效率よく化学エネルギー比变兄る高分子が実用 化レベルで現存するわけではないが, 光エネルギーの 化学的変換と高分子化学の接点といら観点から, 化学

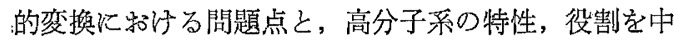
心灶述べることにする。

\section{2. 植物における光化学的变換とそのモデル}

植物の光合成反応は電子の流れという観点から把握

Chemical Conversion of Photoenergy by Polymers.

高分子 28 巻 2 月号 (1979年)
でき，それは古典的な Zスキーム キーム性必ずしも正確ではないが)で表わすとわかり やすい，水から奪われた電子(酸素の発生を伴なら) は, クロロフィル (Chl) を中心とする光合成色素を 含む 2 種の光反応中心 [光化学系 (PS) II 特よび I] により高いエネルギー状態に押し上げられ, 後に通常 の還元電位序列に従って多数の電子伝達 鎖上を移動 し, NADPを還元し, 生成する $\mathrm{NADPH}$ は $\mathrm{CO}_{2}$ の 還元に作用する.

PS II と I は光に上り駆動される一種の電子ポンプ で，電子はそれぞれ約 $0.8 \mathrm{~V}$ の電位差逆らって伝 達され, 合計 $1.6 \mathrm{~V}$ 分のエネルギーが獲得される. 酸素発生之 NADP 還元両サイト間の電位差は約 1.2 $\mathrm{V}$ で，これは水の分解電圧にほ济等しい，1.6 1.2V の差の一部は ATP 生産に利用される. このように光 合成系䋃子の供給源を豊かに存在する水に求めてい る.

Chl の光励起抒よび励起種の動的過程の大略は第 2 図のようになる4). 反応中心 Chl 1 分子に対して約 200 分子存在するアンテナ Chl が主に光励起され,

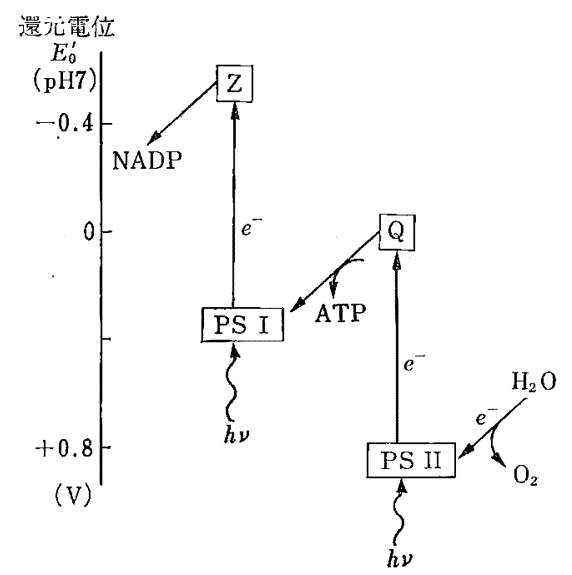

第 1 図 光合成系の概念図 ( $Z$ スキーム) 
励起エネルギーは Chl 分子間を移動し, 反応中心 Chl にトラップされて電荷分離を引き起こす，被分 離電荷は電子伝達サイクルを速かに移動して逆反応を 防ぐ.

光合成の各過程で要する時間 (sec) の逆数の常用対 数をPts とすると, 光量子の吸収, $\mathrm{Chl}$ の湖起・ エ ネルギー移動, 特よび電荷分離は $P t_{s}:$ 15 9 $\left(10^{-15}\right.$ $\sim 10^{-9} \mathrm{sec}$ ) の範囲で起こり, これ続く安定な反応 生成物の形成は $P t_{s}:$ 9 4, さらに電子伝達や醭素反 応が進行するのは $P t_{s}: 4 \sim-1$ 範囲である. 光化学 上注目すべきことは，電荷分離と安定生成物の形成ま でが非常飞速いことである.多数の反応連鎖の秩序だ った配列がこれを可能にしているわけであるが，それ には異相系の matrix が決定的な役割を果たしている ことは疑いない.

著者らの考兄ている化学的変換モデルを第 3 図に示 した5)， $\mathrm{P}_{1} ， \mathrm{P}_{2}$ のいずれかが光励起を受けた後, 相互 間で電荷分離を起こす，その一例は後述する光レドッ クス系である. $\mathrm{T}_{1}, \mathrm{~T}_{2}$ は分離電荷を取り出すための Transfer cycle， $\mathrm{C}_{1} ， \mathrm{C}_{2}$ 注触媒サイトである. 単一 化合物ですべての機能を果たせればそれにこしたこと はないが，光合成系をモデル化し機能分担という観点 から描かれている．このモデルが円滑に反応するため の必要条件は 各構成要素のレドックス対の還元電位 が (1) 特よび (2) 式の関係にあることである.

(暗時) $\mathrm{P}_{1}<\mathrm{T}_{1}<\mathrm{C}_{1}<\mathrm{C}_{2}<\mathrm{T}_{2}<\mathrm{P}_{2}$

（光照射下） $P_{1}>P_{2}$

水を分解して $\mathrm{C}_{1}$ で水素を， $\mathrm{C}_{2}$ で酸素を発生させる には少なくとも光照射下の $\mathrm{P}_{1}-\mathrm{P}_{2}=1.23 \mathrm{~V}$ 以上の電 位差を生ずる系の設定が必要になる，複数以上の光反

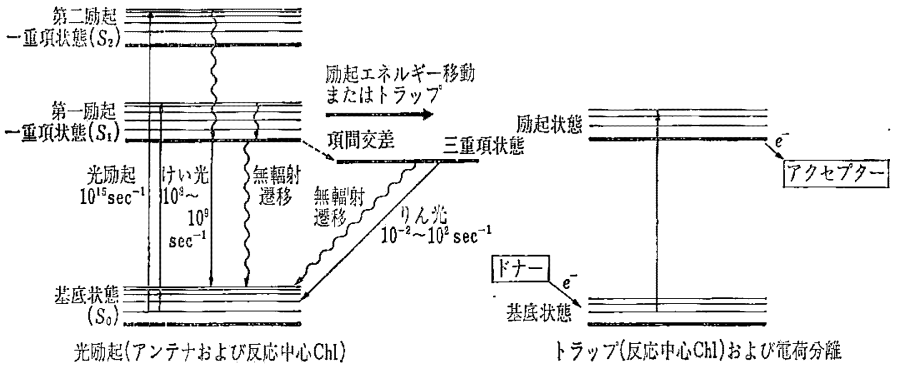

第 2 図 Chl 分子の光励起と励起種の動的過程
応系を直列に組み合わせてそのエネルギー差をかせぐ ことも一つの方法である。

\section{3. 光を電気エネルギーに变える高分子}

\section{3-1. 光レドックス反応}

前述の $\mathrm{P}_{1}, \mathrm{P}_{2}$ のモデルとして光レドックス反応系 を考学ているが，古くから知られ，から可逆性の高い

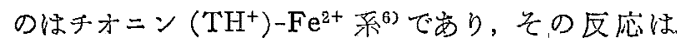
(3)〜(5) 式で表わされる.

$$
\begin{aligned}
& \mathrm{TH}^{+}+\mathrm{Fe}^{2+}+\mathrm{H}^{+} \underset{\text { 谙時 }}{\stackrel{h \nu}{=}} \mathrm{Semi} \text { 型 }\left(\mathrm{TH}_{2} \dagger\right)+\mathrm{Fe}^{3+} \\
& \mathrm{TH}_{2}++\mathrm{Fe}^{2+}+\mathrm{H}^{+} \rightleftharpoons \text { Leuco 型 }\left(\mathrm{TH}_{3}^{+}\right)+\mathrm{Fe}^{3+} \\
& 2 \mathrm{TH}_{2}+\rightleftharpoons \mathrm{TH}_{8}{ }^{+}+\mathrm{TH}^{+} \text {(不均化反応) } \cdots(5 \text { ) }
\end{aligned}
$$

$\mathrm{TH}^{+}$の光励起種の $\mathrm{Fe}^{2+}$ による還元で Semi 型 $\left(\mathrm{TH}_{2}{ }^{+}\right)$が生成与る。 Leuco 型 $\left(\mathrm{TH}_{3}{ }^{+}\right)$生成性主に 不均化 [(5) 式]による。光の ON ・ OFF に上方誇 起される平衡の移動は電極を介して電位変化として現 われる (第 4 図 $)^{7)}$. 照射時・暗時それぞれの平衡電位 の差は光起電力として定義され, $\mathrm{TH}^{+}-\mathrm{Fe}^{2+}$ 系では 約 $150 \mathrm{mV}$ の光起電力を示す.

報告されている光起電力值 ${ }^{83}$ は高くても $480 \mathrm{mV}$ (プロフラビン-EDTA 系 ${ }^{2)}$ ) 程度で, PS II ・I の電 位差 $(800$ ９00 mV) には及ばない，著者らはトルサ フラニンーEDTA 系で条件検索により $844 \mathrm{mV}$ とい ら高い光起電力を得ることができた ${ }^{10)}$. 本系は EDTA の部分的分解を伴い低可逆珄の欠点を持つが，簡単な 光レドックス系でも光合成系に匹敵する光起電力を示 しうることが明らかとなった。

光レドックス系からエネルギーを 取り出す最も簡単な方法は, 電極を 介して光電流を得ることで，それに 以明・暗セ儿型光電池 (第 5 図 ${ }^{102}$ ) を用いるのがよい、トルサフラニン -EDTA 系炕上る定常光電流の量子 効率は吸収光当たり約 $0.2 \%$ であっ。 た.

\section{3-2. 高分子光レドックス反応} 系による変換

フェノチアジン特よ びフェナジン系绝素と アミンの光レドックス 系名で，ポアミンを 用いると光起電力以 1.8〜8.5 倍高くなるこ とを見いだした ${ }^{11)}$.

第 3 図 光エネルギーの化学的変換モデル 


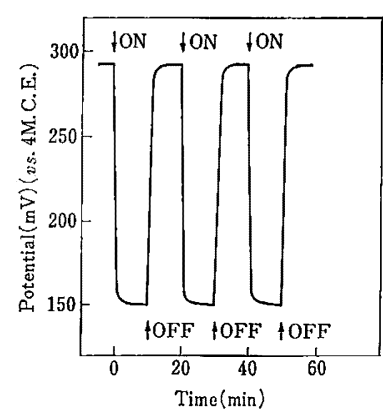

TH: $10^{-5}(\mathrm{~mol} / \mathrm{l})$,

$\mathrm{Fe}^{2+}: 5 \times 10^{-3}(\mathrm{~mol} / \mathrm{l})$,

$\mathrm{pH} 2$ ( $\mathrm{HCl}-\mathrm{KCl}$, buffer soln.)

第 4 図 光の照射・しゃ断に伴

\section{う電位変化パターン}

また第 6 罒に示したように， $\mathrm{TH}^{+}$-ポリアミン系で 一分子中のアミノまた性イミノ基（N-基）数沁応じ て特徵的な光起電力挙動を示した ${ }^{11)}$. 光起電力抽よび ポリアミンのイォン種 それぞれの $\mathrm{pH}$ 依存 性, 可視スペクトル, 特よび NMR から N基の半分がプロトン化

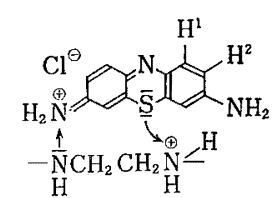

したポリアミンは $\mathrm{TH}^{+}$と（6) 式に示したような bifunctional 相互作用をして拉り, 光励起後の電子移 動が容易になっていると結論された．この機構で第 6 図のジグザグパターンを説明できる.

光レドックス系を一つの高分子鎖上飞組み込むと， 低分子系とは挙動が著しく違ってくる。ポリアクリル 酸に $\mathrm{TH}^{+}$とェチレンジアミン (en) を反応させて得 られた光レドックス反応性高分子 [(7) 式]の水溶液 は光起電力を誘起し，その值の $(\mathrm{en}) /\left(\mathrm{TH}^{+}\right)$モル比 依存性は低分子系 $\left(\mathrm{TH}^{+}\right.$- en) とは著しく異なって效 果が高い(第 7 図 $)^{12)}$.

$$
\underset{\substack{\mathrm{COOH} \\ \text { I }}}{\mathrm{CHCH}_{2}+\cdots \frac{\mathrm{TH}+\text { en }}{\text { dry EtOH }}}
$$

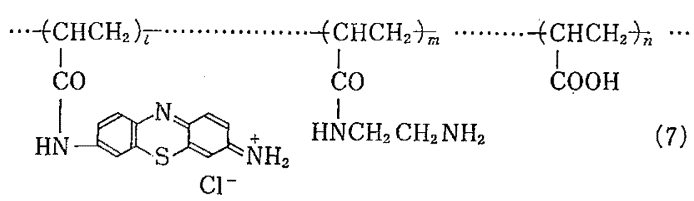

高分子系では低い（en)/(TH+ $\left.{ }^{+}\right)$比でも，反応対が 近傍に存在するため光反応しやすく，一方，(en)/ $\left(\mathrm{TH}^{+}\right)$比が大きい場合, $\mathrm{TH}^{+}$基は分散しているため 活性なセミ型（S）の不均化功抑兄られ，電極不活性 のロイュ型（L) が生成し難く，図の結果となったと

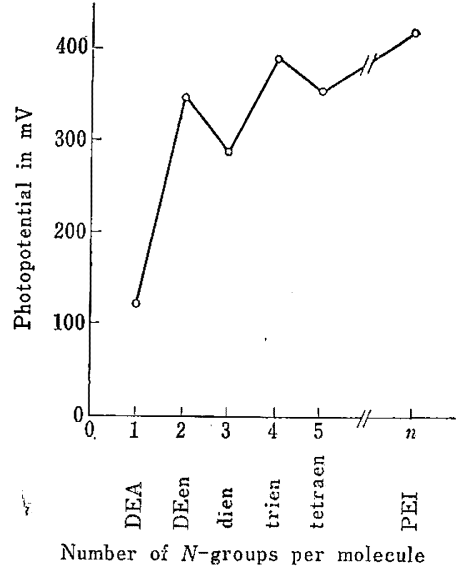

$\mathrm{TH}^{+}: 10^{-5}(\mathrm{~mol} / \mathrm{l})$

$\mathrm{N}$-基： $5 \times 10^{-3}(\mathrm{~mol} / \mathrm{l}), \mathrm{pH} 8$

第 6 図 $\mathrm{TH}^{+}$-ポリアミン系により 誘起される光起電力

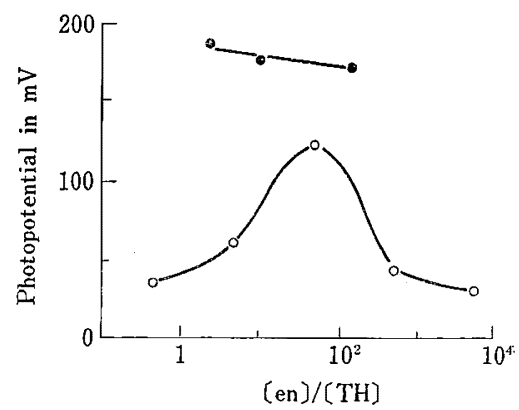

- : 高分子 $\mathrm{TH}^{+}$-en 系 O：低分子 $\mathrm{TH}^{+}$-en 系 $\mathrm{TH}^{+}$単位濃度 $10^{-5}(\mathrm{~mol} / \mathrm{l}), \mathrm{pH} 8$

第 7 図 光レドックス高分子により誘起 される光起電力
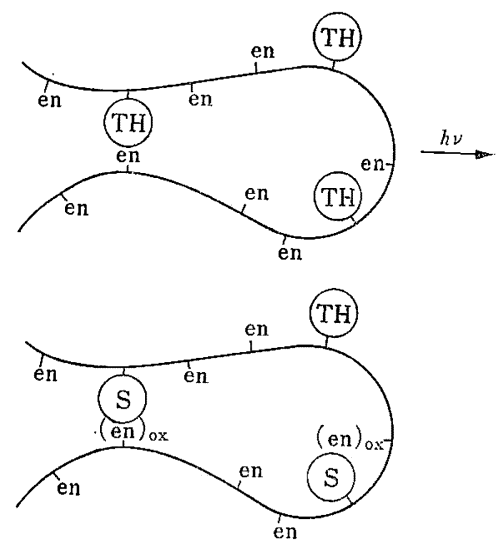

(8)

考光られる [(8) 式].

カチオン型高分子鎖に $\mathrm{TH}^{+}$を結合させると，カチ オン反発により連鎖が延びるため，高分子鎖による電 


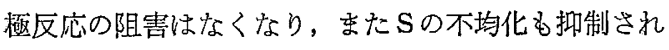
て光起電力は増与 [(9) 式].

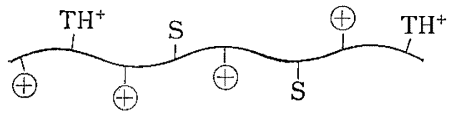

(10) 式のカチオン型高分子 $\mathrm{TH}^{+}-\mathrm{Fe}^{2+}$ 系は低分子 系の約 60 倍の出力を示した ${ }^{13)}$.

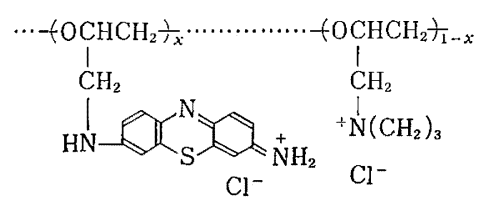

透明電極（例えばネサガラス）を，これとは選択性 の異なる対極と組及合わせて用いると, 全照射薄層型

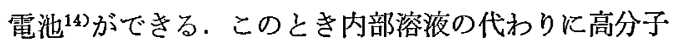
膜やゲルを用いると, 取り扱いが容易で安定性に優れ た半乾式光電池になる15)。ゲルとしてはポリ(エピク ロルヒドリン) と $\mathrm{TH}^{+}$揖よびトリメチルアミンから 誘導された橋かけ高分子 [(11) 式] を用い，これに $\mathrm{Fe}^{2+}$ および少量の $\mathrm{Fe}^{3+}$ を浸透させた. イオン種の 拡散が困難なゲル系にもかかわらず溶液型電池より高 い効率が得られたのは, 水素移動型電子移動機構によ ると栲えられた。

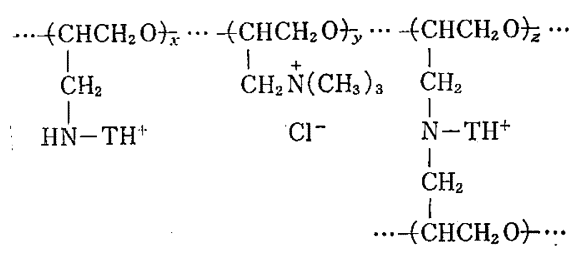

陽イオン, 䧔イオン交換樹脂膜に $\mathrm{TH}^{+}$, アスコル ビン酸をそれ叱吸着させてはり合わせた乾式光電池 も試作されている(16).

\section{3-3. 高分子半導体太陽電池}

高い電導性の高分子半導体で $p-n$ 接合型フィルム が得られ，から安定性の問題が解決されれば，低価格 で成形性に優れ，かつ軽い太陽電池の资現も夢ではな くなる. 最近, 話題を集めたの恃高い電導性 $\left(10^{3} \Omega^{-1}\right.$. $\mathrm{cm}^{-1}$ ) のポリアセチレンフィルム17),18) で, これK八 ロゲン, $\mathrm{AsF}_{5}$ などのアクセプターをドープすると $p$-型に， Naなどのドナーにより $n$-型にできる. 両つ ィルムから $p-n$ 接合を行ない，整流作用が確認され た. バンドギャップは $1.6 \mathrm{eV}$ (約 $770 \mathrm{~nm}$ の光に相 当）で, 太陽光スペクトルの半分以上はカバーでき, 太陽電池としての発展が期待されている.

\section{4. 高分子やミセルなどの反応場における 光エネルギー变換}

光エネルギーを効率よく変換，蓄積するためには反 応場の設計が重要で, 光合成系と同様に異相界面の利 用が要点となる。高分子，ミセル，膜などが提供する ミクロ環境に打ける光反応が注目され，基礎的な検討 が始まっている.

\section{4-1. 高分子の反応場における光反応特性}

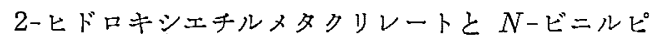
ロリドン共重合体水溶液にアニオン性アゾ色素を吸着 させると，光照射によるtrans-cis 異性化により溶液 粘度は低下し, 暗時で復元する19)。これは photomechanical 系20)の一つのモデルである，高分子に色 素を化学結合させると固相光反応が可能となる潘か， 光特性も大きく影響される.フェノチアジン色素高分 子膜は可逆的光レドックス反応性を示す21),22).

高分子系では孤立 chromophor に比べてェネルギ 一移動が起こりやすいが，一方，局所濃度の高さが励 起錯体生成を容易にし，ェネルギーはトラップされ る $^{23), 24)}$.これらはアンテナ Chl から反応中心 $\mathrm{Chl}$ に至るエネルギー移動を想起させる。

アントラキノン核を有する共重合体はアスコルビン 酸と Fast Red A の反応の光増感剤として低分子系 より效果が高く，これは cage effectにより説明され $ろ^{25)}$. 消光剂学同一分子内に有する共重合体 ${ }^{25)}$, 濃 度消光が起こる条件 ${ }^{26)}$ では分子内消光により效率は低 下する。

\section{4-2. ミセルおよび膜系での光エネルギー変換}

ミセル系では, 界面の著しく高い電場 $\left(10^{3} \mathrm{~V} / \mathrm{cm}\right)$ のために光電荷分離の効率が高くなることが最近明ら かになった 27),28). ラウリル硫酸ナトリウム(SDS), ミセルに可溶化したピレン, ペリレンなどの光イオン 化効率は高く ${ }^{29)}$, また水和電子の収率はミセル分子鎖 長に依存する。

ミセル化テトラフェニルポルフィンー $\mathrm{Zn}$ 錯体 $(\mathrm{Zn}$ TPP) 存触媒として，9，10-アントラキノン-2,6-ジス ルホン酸ジナトリウム(AQDS) そアスコルビン酸 (Asc) Kより光還元すると, 還元体 $\left(\mathrm{AQDSH}_{2}\right)$ が 生成して化学エネルギーが蓄積されたことになり, 光 しゃ断してもその状態を保つ ${ }^{30)}$ (第 8 図). ミセル表 面の電荷が $\mathrm{ZnTPP}^{\dagger}$ と $\mathrm{AQDS}^{-}$の逆反応を防ぎ, また生成する Asc $\left(-\mathrm{H}_{2}\right)$ がミセルにとりこ委れるた め, 電荷分離・蓄積が可能となったと考古られる。

光エネルギー変換で効率低下の原因となる逆反応を 防ぐには, 反応カップルを膜で分離し, 膜を介して電 子や $\mathrm{H}^{+}$の翰送をはかる力法がある31), 内部に Asc 


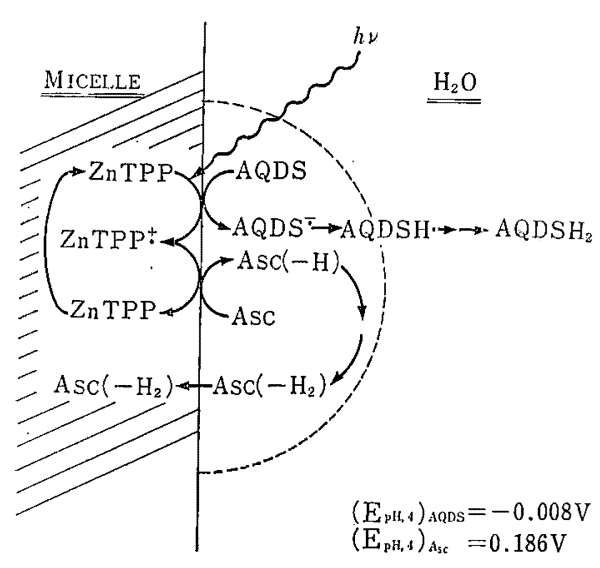

第 8 図 ミセル系での光エネルギー 変換・蓄積

を, 膜中に Chl a を保持したレシチン・ベシクル（リ ポゾーム) を光照射すると， Asc から外側の $\mathrm{Cu}^{2+}$ ヘ

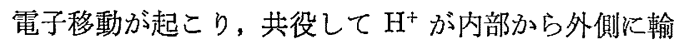
送される32)。へマトポルフィりンジィチルェステルー MnII 錯体を含んだレシチン二分子膜で隔てられた $\mathrm{NaOCl}$ と Asc 間での電子移動が観測されて特り ${ }^{332}$, 二分子膜も光エネルギー変換に利用できると思われ る.

紫膜 (purple membrane) 好塩菌の一種である Halobacterium halobium の細胞膜で，その主成分で 西るバクテリオロドプシンは視細胞の光感受性物質と 同じレチナールを結合している ${ }^{34)}$. 光尤膜内外の 電気的ポテンシャルに逆らって $\mathrm{H}^{+}$を体外飞輸送する ので，利用が期待される ${ }^{35)}$.

\section{4-3. 金属錯体を利用した水の光分解による水素 の生産}

水を光分解して水素と酸素を生産できれば，光ェネ

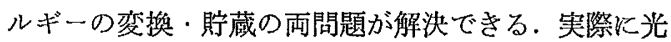
合成細菌のヒドログナーゼは水素を発生している。 こ のような水の光分解は金属錯体を触媒としてはじめて 可能になるであるう。

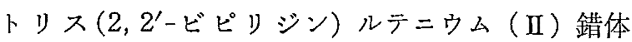
$\left(\mathrm{Ru}(\mathrm{bpy}) \mathrm{3}^{2+}\right.$ ) は光励起 ${ }^{3} \mathrm{CT}$ 状態で還元力が強く, 水を睘元しらる電位を持つこと [(12)式]，一方， Ru (bpy) $3^{{ }^{3+}}$ 錆体は酸化力が強く水定酸化しらる電位を 持っこと [(13) 式]が指摘され ${ }^{36)}$ て以来, 脚光を浴 びるようになった。

$$
\begin{aligned}
& \mathrm{Ru}(\mathrm{bpy}) 3^{3+}+e^{-} \longrightarrow\left({ }^{3} \mathrm{CT}\right) \mathrm{Ru}(\mathrm{bpy}) \mathrm{s}^{2+} \text {, } \\
& E^{0}=-0.83 \mathrm{~V} \\
& \mathrm{Ru}(\mathrm{bpy}) \mathrm{8}^{8+}+e^{-} \longrightarrow \mathrm{Ru}(\mathrm{bpy})_{3^{2+}} \text {, } \\
& E^{0}=+1.27 \mathrm{~V}
\end{aligned}
$$

実際には $\mathrm{Ru}(\mathrm{bpy}) \mathrm{s}^{2+}$ 錯体水溶液 $\left(\lambda_{\max }=452 \mathrm{~nm}\right)$
に光照射しても水素は発生せず，発光して $S_{0}$ にもど ってしまう．この理由として，䤮体から水への電子移 動の障壁, 逆電子移動が速い，などが考光られてい る. あるいは水素発生汇必要な 2 電子移動が stepwise 炕起こって最初の段階が 律速となる37) と（註： $\mathrm{H}^{+}+e^{-} \rightarrow \mathrm{H}$ の $E^{0}$ は $\left.-2.106 \mathrm{~V}\right)$, この錯体では還 元電位が足りないことになる.

水の光分解を可能沈するには，柾水的反応環境の設 定, 分離電荷を引き離す工夫, $\mathrm{Ru}$ 核の集合状態を作 り多電子の一段階移動を可能にする，などの方法が考 党られ, 高分子反応場やミセルの利用は一つの試みで

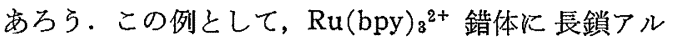
キル基を導入し [(14) 式], ガラス板上に単分子膜を 形成させて光照射すると, 水の分解により水素之酸素 が発生すると報告され党，話題を呼んだが，この反応 は再現されなかった。同様な単分子膜やフィルムで水 の光分解が試みられたがまだ成功していない。

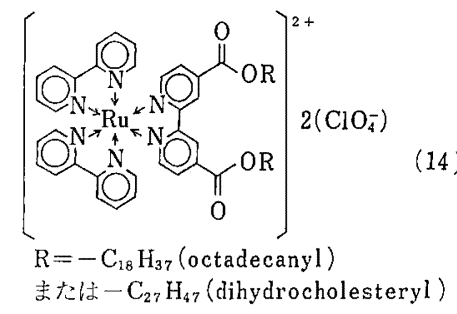

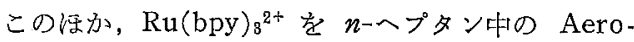
sol OT 逆ミセル中の水プールに溶解すると, 水プー ルの大きさにより発光挙動が変化することも最近わか りつ要る399.

以上のように，ミクロ環境の設計による励起種の動 的過程の制御により，反応性を変えることる可能なの で，基礎的知見の集積により，高分子の反応場やミセ ルの設計により目的とする光反応が将来可能となるで 两万弓。

\section{5. 高分子を利用した光エネルギーの蓄積}

植物は炭酸ガスの固定還元により $114 \mathrm{kcal} / \mathrm{mol} の$ エネルギーを蓄積している，炭酸ガスの共重合固定40) を水と光により還元的に行な兄れば光エネルギーの変 換・蓄積になる。

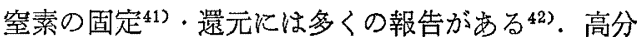
子トリフェニルホスフィン-Co 錯体の窒素固定能は 低分子系上り優れている ${ }^{43}$. や性り水之光に上り還元 できれば光ェネルギー蓄積になる。

ノルボルナジェン (NBD) は增感剤 $(\mathrm{CuCl}$ など) 共存下の光照射によりクロドリシクレン $(\mathrm{Q})$ 飞異性 化し, $\mathrm{Pd}(\mathrm{NBD}) \mathrm{Cl}_{2}$ などの触媒添加により $\mathrm{NBD}$ に 
もどる際に発熱 ( $\Delta H=-21 \mathrm{kcal} / \mathrm{mol})$ する44). 増感 片と触媒をとれぞれ高分子化して相互の分離を行なう システム化が検討されている.

水素を生産する光合成細菌のヒドログナーゼを葉緑 体と結合すると，光照射炕上り水素を発生するが，同 時に生ずる酸素により失活しやすい，分離した PS I と PS II 別々に高分子マイクロカプセル化し，水 素発生娍功している45).

\section{6. おわりに}

光エネルギーの化学的変換の要点は, 可視光による 電荷分離, 電子伝達, 特よび合成サイトの分子設計化 ある．椂色植物の光合成系をながめればながめる汪 ど，その機構は巧妙にして複雑怪奇である。また自然 と人工との隔たりの距離空痛感する。特炕高分子科学 の寄与はこの分野でも大変重要になってくるであるう が, 高分子鎖上の秩序配列, 高分子ドメイン中の反応 制御, 異方性反応環境の設計, へテロ界面や光励起系 の直結設計など, まだ基礎研究の欠除している向きが 感じられる。

本稿は, 高分子科学の光エネルギー変換に括汀るま だわずかな寄与している部分しか紹介できず，悻管を 引き受けたことを痛く後悔しつつ，皆様のご寛容を乞 うしだいである。

\section{文献}

1）柴田和雄，今村 昌，池上 明編著：太陽エネルギ 一の生物・化学的利用, 学会出版センター (1978)

2) 山田 溚：第 24 回高分子夏季大学要旨集 (1976) p 26; 第 26 回同誌 (1978), p 117

3) R. Hill, F. Bendall: Nature, 186, 136 (1960)

4) R. Govindjee: Bioenergetics of Photosynthesis, Academic Press (1975)

5）金子正夫：第 11 回 高分子化学の未解決問題 シン ポジウ $\Delta$ (1976) p 21

6) E. Rabinowitch: J. Chem. Phys., 8, 551, 560 (1940)

7）金子正夫，山田 瓘：理研報告， 52，210 (1976)

8) 神谷信行, 大河原 信: 電気化学, 36, 506 (1968); 38, $273(1970)$

9) M. Eisenberg, H.P. Silverman: Electrochim. Acta, 5, 1 (1961)

10) M. Kaneko, A. Yamada: J. Phys. Chem., 81, 1213 (1977)

11) M. Kaneko, S. Sato, A. Yamada: Makromol. Chem., 179, 1277 (1978)

12) M. Kaneko, M. Sugai, A. Yamada: ibid., 179, 2431 (1978)

13) K. Shigehara, H. Sano, E. Tsuchida: ibid., 179, 1531 (1978)

14) W.D.K. Clark, J.A. Eckert: Solar Energy, 17, 147 (1975)

15) K. Shigehara, M. Nishimura, E. Tsuchida:
Bull. Chem. Soc. Japan, 50, 3397 (1977)

16）吉田瑞子, 押田勇雄：応用物理， 33，34 (1964)

17) H. Shirakawa, T. Ito, S. Ikeda: Makromol. Chem., 179, 1565 (1978)

18) C. K. Chiang, C. R. Fincher, Jr., Y.W. Park, A. J. Heeger, H. Shirakawa, E. J. Louis, S.C. Gau, A.G. MacDiarmid: Phys. Rev. Lett., 39, 1098 (1977)

19）根岸直樹, 高橋正行, 岩沢 晃, 松山应太郎, 篠 原 功：日化，1977，1035

20）長田義仁：機能 性高分子，共立出版（1974） p 597

21) H. Kamogawa: J. Appl. Polym. Sci., 13, 1883 (1969)

22) H. Kamogawa, H. Hasegawa: ibid., 17, 745 (1973)

23）田附重夫：光感応莝高分子，高分子学会予稿集， 27, 652 (1978)

24) 岡本健一：高分子, 23, 514 (1974)

25) T. Nakahira, E. Shinomiya, T. Fukumoto, S. Iwabuchi, K. Kojima: Eur. Polym. J., 14, 317 (1978)

26) T. Nakahira, C. Minami, S. Iwabuchi, K. Kojima: Makromol. Chem., 179, 1593 (1978)

27）松尾 拓：化学の領域, 32, 521 (1978)

28 松尾 拓：日化第 38 回秋季大会, 特 $1 \mathrm{G} 17,1127$ (1978)

29) S.C. Wallace, M. Grätzel, J.K. Thomas: Chem. Phys. Lett., 23, 359 (1973)

30) K. Kano, K. Takuma, T. Ikeda, D. Nakajima, Y. Tsutsui, T. Matsuo: Photochem. Phoiobiol., 27, 695 (1978)

31) M. Calvin: 化学, 33, 254 (1977)

32) 梁原和枝, 嶄島喜則, 䤮柄光則: 日化第 37 回春季 大会 (1978) p 440

33) I. Tabushi, M. Funakura: J. Am. Chem. Soc., 98, 4684 (1976)

34) D. Oesterhelt, W. Stoeckenius: Nature New Biology, 233, 149 (1971)

35）池上 明：太陽エネルギーの生物・化学的利用, 学会出版センター (1978) p 101

36) C. Creutz, N. Sutin: Proc. Nat. Acad. Sci. U.S., 72, 2858 (1975)

37）金子正夫：高分子金属錯体, 化学同人（1978） p 141

38) G. Sprintschnik, H. W. Sprintschnik, P.P. Kirsch, D.G. Whitten: J.Am. Chem. Soc., 98, 2337 (1976)

39）呇村芳実：太陽エネルギーの生物・化学的利用, 学会出版センター (1978) p 186

40) S. Inoue, H. Koinuma, T. Tsuruta: Polym. Lett., 7, 287 (1969); Makromol. Chem., 130, 210 (1969)

41) 伊藤 卓, 山本明夫：化学，32，22（1976）

42) G. N. Schrauzer, G.W. Kiefer, K. Tano, P. A. Doemeny: J. Am. Chem. Soc., 96, 641 (1974)

43）稻沼正雄, 仲野義晴, 栗村芳実, 小出幹夫, 土田 英俊：高分子学会予稿集，27，302 (1978)

44) D. P. Schwindiman, C. Kutal: Inorg. Chem., 16, 719 (1977)

45）北島昌夫：太陽エネルギーの生物・化学的利用, 学会出版センター-(1978) p 63 